Marketing in Asia Group

Asian Journal of Business Research

Volume 9 Issue 2, 2019

ISSN 2463-4522 e-ISSN 1778-8933

DOI: $10.14707 / a j b r .190062$

\title{
How Millennials' Knowledge, Trust, and Product Involvement Affect the Willingness to Pay a Premium Price for Fairtrade Products?
}

\author{
Hasan Aksoy \\ Department of International Trade and Logistics, Gaziantep University, Turkey \\ Ceren Özsönmez \\ Department of International Trade and Logistics, Gaziantep University, Turkey
}

\begin{abstract}
This study provides, through a survey of 200 Millennials, an empirical analysis of the influences of Fairtrade (FT) knowledge, trust in FT and product involvement on the willingness to pay (WTP) a premium for Fairtrade products. The objectives of this study were to examine the factors influencing the Millennials' willingness to pay a premium price for Fairtrade products. To succeed in these objectives, this paper improved on the model of Millennials' willingness to pay a premium for Fairtrade products. Based on the questionnaires from Turkey, the model was confirmed by the structural equity model. The results demonstrate that FT knowledge is the basis of antecedent trust and product involvement. The findings indicate that there is not a significant relationship between FT knowledge and WTP. It was further revealed that a willingness to pay a premium for Fairtrade products was positively affected by the trust in FT and product involvement. Besides, it may be inferred that the trust in the Fairtrade movement influences consumer's product involvement. The findings of the study have significant implications for the development of the consumption of Fairtrade products and understanding the perception by Millenials of Fairtrade products.
\end{abstract}

Keywords: Fairtrade, Product Involvement, Willingness to Pay a Premium, Trust in Fairtrade

Publication Details: Received 13 Nov 2018; Revised 16 Apr 2019; Accepted 16 July 2019 


\section{Introduction}

The market for the consumption of Fairtrade (FT) goods continues to grow globally. Fairtrade sales amounted to a total of 7.9 billion $€$ in 2016, which reflects an increase of approximately \% 10 on the figures for 2015 (FLO, 2018). However, contrary to expectations, emerging markets are more ethically and environmentally conscious compared with developed economies. For example, Turkey ranked sixth in the global top 20 in shopping preferences for ethically conscious products in 2017 (Euromonitor, 2018). Against the backdrop of this dynamic growth in the global Fairtrade market, understanding the reasons why consumers buy Fairtrade products (Harrison et al., 2005; Fraj \& Martinez, 2006; Pinto et al., 2011; Sama et al., 2018), how information about ethical issues impacts consumer attitudes (Shaw \& Shiu, 2002; Carrigan \& Attalla, 2001; Maignan \& Ferrell, 2004), and why consumers are willing to pay a premium for Fairtrade products (Janssen \& Hamm, 2012) have become important questions for managers and researchers of global companies.

Studies have stressed that, over the last few decades, consumption habits have begun to change and consumers are now using more sustainable products in their daily lives (Cerri et al., 2018). Consumers demonstrate sympathy towards companies that show generosity to their suppliers and they have shown a willingness to pay a premium price for Fairtrade products (Reinstein \& Song, 2012). Fairtrade is considered a social movement by an increasing number of young consumers. Millennials have positive beliefs and attitudes about Fairtrade compared with previous generations. Research shows that young consumers value product features in their preference for Fairtrade product involvement. The main purpose of the research was to analyze the generation that plays a significant role in the purchasing of products and the services across so many different sectors. The study examines the Millenial's particular interest in Fairtrade products, and beyond this, the research focuses on factors such as trust, a willingness to pay a premium, and Fairtrade knowledge. The current paper incorporates the multiple frameworks of product involvement and the Fairtrade perceptions of O'Cass (2000), De Pelsmacker (2007), and Castaldo et al. (2009). The present model focuses on answering the following questions. Firstly, to what degree do trust, product involvement, and knowledge of Fairtrade efforts influence the willingness to pay a premium? Second, how does knowledge of Fairtrade impact on both Fairtrade product involvement and trust? Third, to what degree does trust interact with Fairtrade product involvement?

The introduction section of the study is a discussion of the willingness to pay a premium for Fairtrade products and develops the hypotheses of the model. Methodology description, sample examination, and measures are in the ensuing sections. The final sections show the results and offer a guide for future research to contribute to the literature. 


\section{Literature Review}

\section{Fairtrade}

A Fairtrade approach is intended to improve the environmental, social and economic status of producers in the developing world through the setting of standards of trade (Raynolds et al., 2007). Fairtrade is one of the approaches that seek to balance the inequalities of traditional trade, and support producers for sustainable development in underdeveloped countries and attempts to achieve this by maintaining a superior marketing environment and creating new understanding (Krier, 2001; Lukas, 2015). Although Fairtrade products are considered a niche market, they are sold through the largest retailers all over the world (Davies \& Crane, 2003). The market for Fairtrade goods continues to grow globally and the most sold Fairtrade products to date have been chocolate, clothes, tea, and textiles (Jones et al., 2003; Raynolds, 2012; Rousseau, 2015). Pérez and De Los Salmones (2018) documented that the relationship between buying behavior and the positive attitude of consumers towards fair trade products has resulted from several factors such as product quality, price, knowledge, availability, and ethical attributes. Fairtrade retailers hold an advantage by conveying to the consumer the environmental, ethical and fair labor benefits behind the making of the products (Rashid \& Byun, 2018).

\section{The Millennial Generation}

The generational cohort theory was first proposed as a way to divide the population into segments and can be defined by birth years (Lissitsa \& Kol, 2016). Millennials (generation Y) includes individuals who were born between 1982 and 2001 (Stoica et al., 2015). Millennials constitute $25 \%$ of the population of Turkey and will account for approximately $70 \%$ of the workforce in Turkey by 2025 (Tükel, 2014; Edelman, 2017). The present study focuses on the consumer behavior of Millennials for two reasons: Firstly, they have the greatest spending power of any generation and they are willing to consume (Moses, 2000; Forbes, 2018). Secondly, they are becoming an effective demographic group that focuses on ethical and environmental issues (Muhcina and Popovici, 2015; Young and McCoy, 2016). Social responsibility is one of the issues that are advocated strongly by Millennials (Barber et al., 2010). For example, Rousseau (2015) analyzed that Millennials represented the largest group who assigned the highest value to Fairtrade products.

\section{A Willingness to Pay a Fairtrade Premium}

Researchers have demonstrated a significantly increased interest in price premium that consumers are willing to pay (known as WTP). Previous research has defined the WTP as the premium to be paid for a product or service by consumers when ethical attributes in the goods or services are communicated (Carter, 2009). Ethical approaches have been playing a significant role in the behavior processes of consumers in recent years (Creyer \& Ross, 1997). D'Amico et al. (2016) confirmed that consumers' buying behavior is impacted by demographics in terms of age, gender and nationality. For example, Park (2018) stressed that female, younger, and highly educated consumers are the consumers most willing to pay a premium for fair trade products. Furthermore, several studies have claimed that consumer characteristics affect the WTP a premium as well as purchase decisions (Adesope et al., 2010; Singh 
\& Pandey, 2018; Murakami, 2018). Generally, Fairtrade products are likely to be more expensive than competing ones. A Fairtrade premium might be directly related to the following: 1) higher costs of manufacturing or certification, 2) a guaranteed price for producers, and 3) a percentage of the price set aside for development projects in the producer community (Shaw \& Clarke, 1999).

\section{Hypotheses Development}

Figure 1 outlines the hypotheses tested in the research. This study seeks to analyze relations between FT knowledge, trust in Fairtrade, product involvement, and WTP a premium while focusing on Turkish Millennials. FT knowledge, trust in FT, and product involvement, equally affect the behavior of the ethical consumer and have been stressed in many marketing and business journals. Hence, the present study identifies benefits and advantages from criteria based on the consumer behavior of Millennials.

\section{Fairtrade Knowledge}

Knowledge is the explication of information which is derived from a person's reflections or experiences. Further, knowledge helps to interpret and specify the present options open to consumers (Blackwell et al., 2001). Knowledge is one of the strongest indicators of consumer behavior and helps customers evaluate what they know about a product and the movement of that product (Dodd et al., 2005). Within the scope of consumer research, knowledge is defined as the factor which influences every step of a buying decision (Laroche et al., 2003; Becchetti \& Rosati, 2007).

\section{Fairtrade Knowledge and Trust}

The degree to which a consumer actually trusts a product is largely correlated with their knowledge of the product and its overall characteristics. A lack of trust in a Fairtrade product may be caused by a lack of knowledge, and this situation may influence the level of sales for certain Fairtrade products (De Pelsmacker \& Janssens, 2007). While prior research exists to support the relationship between trust and knowledge in the Fairtrade movement (Davenport \& Low, 2013), few studies have analyzed the specific influence of knowledge about Fairtrade and its impact on Fairtrade itself. Ultimately, it was concluded that consumers with a high degree of knowledge were more likely to trust a Fairtrade product because of its claimed ethical standards in further impacting on Fairtrade purchasing behavior (Wang et al., 2009; Low \& Davenport, 2005). A significant relationship is expected between trust and Fairtrade knowledge. Thus, it was hypothesized that:

H1a FT knowledge has a significant impact on Millennials' trust in FT.

\section{Fairtrade Knowledge and Product Involvement}

Previous research has indicated certain factors that affect knowledge regarding Fairtrade, such as product involvement, WTP a premium, and purchasing involvement (Ladhari \& Tchetgna, 2015). Generally speaking, there have been considerable effects in terms of FT knowledge on consumer' involvement with FT products (Baker et al., 2002; Lamb \& Liesch, 2002; Park \& Moon, 2003). In addition, if the customer does not have an interest in the product, he or she will likely have a knowledge deficiency 
regarding the product and consequently will feel uncertain about purchasing the product (Lin \& Chen, 2006). Product information convinces the consumer to purchase the brand and to pay a premium for a product or service. For example, Starbucks with its information about Fairtrade coffee directly communicates with consumers and positively affects consumer behavior (Carter, 2009). Thus, it was hypothesized that:

H1b FT knowledge has a significant impact on Millennials' FT product involvement.

\section{Fairtrade Knowledge and WTP a Premium Price}

Previous studies portray a significant relationship between knowledge and behavior in the consumer purchasing of Fairtrade products (Tallontire et al., 2001; Becchetti \& Rosati, 2007; Liang, 2012; Rashid \& Byun, 2018). Furthermore, knowledge of Fairtrade is associated with a willingness to pay a premium (Trudel \& Cotte, 2009). The WTP a premium is an element of the Fairtrade decision-making process. Moreover, a consequence of FT knowledge on the part of the consumer means that consumers are WTP a premium more for ethical products rather than for non-ethical products. Furthermore, De Pelsmaker et al. (2006) stressed that a lack of knowledge regarding a Fairtrade product discourages purchasing intentions in favor of Fairtrade products. Similarly, Pedregal and Ozcaglar-Toulouse (2011) state that consumers may refuse to purchase Fairtrade products if they lack information about them. Contrary to these findings, Ajzen et al. (2011) have indicated that, generally, knowledge is not a significant element in the decision-making process of consumers. These different findings relating to the role of knowledge show that Fairtrade knowledge may be an important element in Millennials WTP a premium and should be considered in the present study. It is argued that the WTP a premium price is profoundly affected by Fairtrade knowledge. Thus, it was hypothesized that:

H1c FT knowledge has a significant impact on Millennials WTP a premium price.

\section{Trust}

Trust is generally explained as a person's willingness to rely on the actions of others, based on an expectation of trust (Rotter, 1971; Barber, 1983; Young, 2009). Previous studies have focused on different types of trust: generalized trust (Rotter, 1967; Bo et al., 2017), organizational trust (McKnight et al., 1998; Felix et al., 2017; Liu et al., 2018) and ethical, Fairtrade trust (Castaldo et al., 2009; Davenport \& Low, 2013; Langen \& Adeneuer, 2013; Hong, 2015). Mostly, consumers tend to consider a company which is engaged in social responsibility activities through fair trade as trustworthy. This approach helps companies to improve corporate performance and competitive advantage (McClure \& Seock; 2018).

\section{Trust and Product Involvement}

Factors of trust strengthen the product involvement of Fairtrade and the main influencer of the product involvement in these products is consumer trust in the Fairtrade approach. This trust will be encouraged by stories that consumers have read about Fairtrade products and the farmers involved in the Fairtrade movement (Jones \& Williams, 2012). Product involvement might also impact perceptions of Fairtrade 
products and relieve the influences of the source factor on consumer trust. Consumer trust and product involvement in Fairtrade may also interact with each other (Petty et al., 1981; Atkinson \& Rosenthal, 2014). Thus, it was hypothesized that:

H2a Trust in FT has a significant impact on Millennials' FT product involvement.

\section{Trust and WTP a Premium Price}

Previous studies have advocated that eco-friendly shopping behavior has been affected by consumer trust (Govindasamy et al., 2001; Janssen \& Hamm, 2014; Hobbs \& Goddard, 2015), and individuals who declare greater trust may be more willing to pay more (Zak \& Knack, 2001; Wiser, 2007). Carson (1991) stated that consumers trust their feelings and primary values when they need to elicit their willingness to pay. According to Castaldo et al. (2009), consumers' trust in Fairtrade products brings a high level of brand loyalty and a willingness to pay a premium price for the product (Ribbink et al., 2004; Castaldo et al., 2009). Lòpez-Mosquera et al. (2014) also indicate that consumers who are not willing to pay a premium protest against higher prices because they do not trust the system. Lack of trust and higher prices are the most commonly considered reasons for being the main barriers as to why non-consumers do not buy organic products (Hughner et al., 2007; Wier et al., 2008). Gerrard et al. (2013) found that the presence of organic certification logos affected UK consumers' willingness to pay a premium and the level of trust in organic foods. All of these studies indicate that trust is a predictor that may be used in situations where the willingness to pay a premium price and product involvement hampers the decision-making process. Thus, it was hypothesized that:

H2b Trust in FT has a significant impact on Millennials' WTP a premium price.

\section{Product Involvement and WTP a premium price}

Extant literature drawn from marketing studies indicates the effect of identity and the social group. According to Traylor (1981), product involvement reflects that a specific product category might be central to an individual's life and their relationship with their social group. According to Strong (1996), ethical consuming references long-term social and environmental issues. This statement is considered an evaluation of the relevance of the involvement and the principles of Fairtrade certified products. Product involvement is a promising basis for Fairtrade purchasing decisions. Thus, it is proposed that a promising new approach called Fairtrade product involvement could be a predictor of the Fairtrade product purchasing decision process. Several studies have reported the relationship between a Fairtrade consumer's product involvement and willingness to pay a premium price. High involvement is defined as personal relevance (Greenwald \& Leavitt, 1984; Nijssen et al., 1995), and consumers who have a high involvement in Fairtrade products are willing to pay a premium price for Fairtrade coffee (De Pelsmacker et al., 2005). Shaw and Clarke (1999) found that product involvement, price and availability, have a significant identifying role on ethical behavior. Consumers who are elderly, without children, and are highlyinvolved Fairtrade individuals, are willing to pay more for fair trade products (Sriwaranun et al., 2015; Van Den Broeck et al., 2018). Thus, it was hypothesized that: 
H3 FT product involvement has a significant impact on Millennials' WTP a premium price.

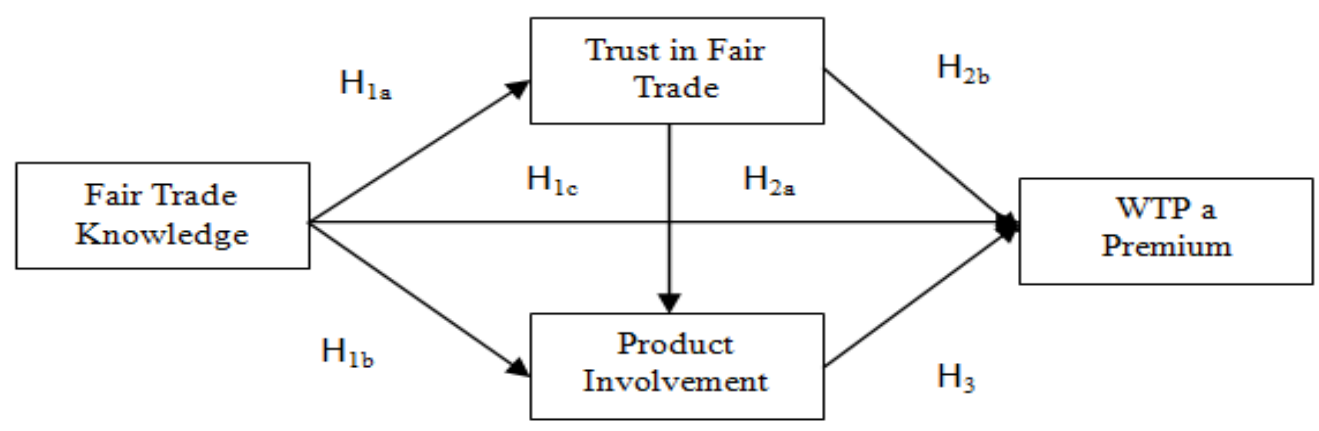

Figure 1: Research Framework

\section{Material Methods}

\section{Sample}

During the collection of data for the study; of the more than 300 respondents who completed questionnaires, and after cleaning the data; it was determined that 200 of them had completed the surveys in full and in usable form, revealing a response rate of $67 \%$. The study focused on Millennials, because, when the characteristics of Generation Y are compared to former generations, it can be stated that socially responsible products are preferred more often by consumers in Generation Y (Bhaduri \& Ha-Brookshire, 2011). Further, Generation Y has indicated positive sentiments about sustainability, fair trade and recycled apparel products (Hwang et al., 2015; Hill and Lee, 2012). The sample was gathered from one of the largest universities in Turkey and was delivered to university students aged 18 years and older. Research assistants promoted the survey and the survey was handed out and completed in class voluntarily by students. Students were first asked whether they have ever shopped for Fairtrade products and they were then invited to answer the questionnaire. Each participant was asked to answer a set of questions regarding Fairtrade products. The survey participants' demographic characteristics are shown in Table 1. For the full sample, 53\% of the respondents were male, and $84.5 \%$ of the sample was studying for a Bachelor's degree. 
Table 1: Demographic Characteristics

\begin{tabular}{|c|c|c|c|c|c|}
\hline Gender & f & $\%$ & Hometown & $\mathbf{f}$ & $\%$ \\
\hline Female & 94 & 47 & Marmara Region & 15 & 7.5 \\
\hline Male & 106 & 53 & Aegean Region & 24 & 12 \\
\hline \multirow[t]{2}{*}{ TOTAL } & 200 & 100 & Mediterranean Region & 31 & 15.5 \\
\hline & \multirow{3}{*}{$\mathbf{f}$} & & Black Sea Region & 12 & 6 \\
\hline \multirow{2}{*}{ Education Level } & & \multirow{2}{*}{$\%$} & Central Anatolian Region & 12 & 6 \\
\hline & & & South-Eastern Anatolian Region & 9 & 49 \\
\hline Associate Degree & 4 & 2 & Eastern Anatolian Region & 8 & 4 \\
\hline Bachelor's Degree & 169 & 84.5 & TOTAL & 200 & 100 \\
\hline Master's or Doctorate & 27 & 13.5 & & & \\
\hline TOTAL & 200 & 100 & & & \\
\hline
\end{tabular}

Note: $\mathrm{f}$ - Number of participants

\section{Scale Validity and Reliability}

The five variables of the study are Millennials' Fairtrade knowledge (FTK), Millennials' product involvement (PI), Millennials' trust (T), and willingness to pay a premium (WTP) for Fairtrade products. The study adopted items relating to Fairtrade knowledge from De Pelsmacker and Jansen (2007), product involvement items from Zaichkowsky (1985) and O'Cass (2000), trust and willingness to pay premium items from Castaldo et al. (2009). All of these measurement items had 5-point scales ranging from $1=$ strongly disagree to $5=$ strongly agree. For hypothesis testing of the study, structural equation modeling (SEM) was employed as a data analysis technique. SEM is a statistical analysis technique with many variables which is used to explore structural relationships. This technique is combined with multiple regression analysis and factor analysis which is used to analyze the structural relationship between measured variables and confidential constructs. There are many studies in the literature about the concept of Fairtrade referenced by SEM (Kim et al., 2010; Pelsmacker \& Janssens; 2006, Poelman et al., 2008). Table 2 includes the standardized factor loadings, standardized errors, composite reliabilities (CR), average variances extracted (AVE) and Cronbach alpha values. The minimum loading for an ideal model should be at 0.70 or above. Composite reliability and AVE were calculated for all variables included in the model. In terms of the reliability of a measure, composite reliability values of 0.60 or above were considered acceptable. All composite reliabilities were above the standard $(.80, .81, .93$, and .89). The recommended value of 0.50 for AVE was also achieved for all variables $(.57, .51, .66$, and .73) (Fornell \& Larcker, 1981). Cronbach's alpha values were also calculated to determine whether our four constructs were reliable or not (Nunnally, 1978). The results of the empirical study displayed Cronbach's alphas as $0.792,0.807,0.928$, and 0.887 for Fairtrade knowledge, product involvement, trust and willingness to pay premium, respectively. The reliability of the constructs were found to be within the frequently accepted range (exceed 0.70), which is listed in Table 2. Structural equation modelling (SEM) was employed to test the suggested hypotheses in the model and the scales fit the data understandably well for the model. The non-normed fit index (NNFI=.921), Goodness of Fit Index (GFI=.913) and Comparative Fit Index $(\mathrm{CFI}=.969)$ were all greater than the criteria of .90. The RMSEA value for the sample 0.053 indicated a good fit. The adjusted goodness-of-fit index (AGFI=.878) was above the recommended threshold value of .80 .

Table 1: Demographic Characteristics 
Table 2: Measurement Model

\section{Fairtrade Knowledge}

Fairtrade purposes are aimed at developing better trade conditions for workers and farmers in developing countries

Fairtrade makes an effort to pay the fairest prices to producers in developing countries

Fairtrade makes an effort towards sustainable development and/or the disadvantaged producers in developing countries

Composite reliability $=.80$

$A V E=.57$

Cronbach's Alpha $=.79$

\section{Trust}

You can always have confidence in Fairtrade products

I trust Fairtrade products

Fairtrade products are trustworthy

I count on Fairtrade products

Composite reliability $=.81$

$A V E=.51$

Cronbach's Alpha $=.93$

\section{Product Involvement}

Fairtrade products mean a lot to me.

Fairtrade products are a significant part of my life.

I have a very strong commitment to Fairtrade products that would be hard to break.

I consider Fairtrade to be a very important part of my life.

Composite reliability $=.88$

$A V E=.66$

Cronbach's Alpha $=.81$

\section{Willingness to Pay a Premium for Fairtrade Products}

I'm willing to pay more for Fairtrade products.

I'm keen to pay a higher price for Fairtrade products

Buying Fairtrade products seems proper to me even if they cost more

Composite reliability $=.89$

$A V E=.73$

Cronbach's Alpha $=.89$

\section{Note: CMIN/DF: 1.567; GFI: 0.913; CFI: 0.969; AGFI: 0.878; NFI: 0.921; IFI: 0.970; RMSEA: 0.053}

Also, standard deviations, means, and correlation values, for all of the four constructs are shown in Table 3. When all information and the acceptable values above are considered, according to the measurements, this model is reliable and valid. Correlations among Fairtrade knowledge, product involvement, trust and WTP a premium are listed in Table 3. Largely, the correlation values and the descriptive statistics are in the right direction and below 1 are valid, also in the confidence interval as expected. In light of this information, the FTK has a positive and significant correlation with product involvement, trust and WTP a premium $(\mathrm{r}=.299$, $\mathrm{p}<0.01 ; \mathrm{r}=.372, \mathrm{p}<0.01 ; \mathrm{r}=.195, \mathrm{p}<0.01)$. Both product involvement and trust demonstrate a positive and relatively strong relationship with WTP a premium $(\mathrm{r}=$ $.544, \mathrm{p}<0.01 ; \mathrm{r}=.471, \mathrm{p}<0.01)$. Trust also demonstrates a positive relationship with product involvement $(\mathrm{r}=.448, \mathrm{p}<0.01)$.

Table 3: Correlations \& Discriminant Validity

\begin{tabular}{ccccccc}
\hline Variables & S.D. & Mean & FTK & PI & T & WTP \\
\hline FTK & .74964 & 4.0303 & $\mathbf{0 . 7 5 5}$ & & & \\
PI & .83220 & 3.2771 & $.299^{* *}$ & $\mathbf{0 . 7 1 4}$ & & \\
T & .82679 & 3.5937 & $.372^{* *}$ & $.544^{* *}$ & $\mathbf{0 . 8 1 2}$ & \\
WTP & .95943 & 3.2900 & $.195^{* *}$ & $.448^{* *}$ & $.471^{* *}$ & $\mathbf{0 . 8 5 4}$ \\
\hline
\end{tabular}

Note: $* * \mathrm{p}<0.01$ 
For the determination of the discriminant validity of the model, the square root of the AVE value of a variable should be larger than the correlation values of the variable. In this case, it can be said that the model has discriminant validity (Fornell \& Larcker, 1981).According to the results obtained, it can be seen that validity is provided in the variables of the model. Table 3 shows the discriminant validity results.

\section{Structural Model Testing}

Structural equation modeling (SEM) was employed to test the suggested hypotheses in the model. Table 4 includes the results of the sample's consumer attitudes towards Fairtrade products. Since it is accepted that the hypotheses with a p-value below 0.001 are supported, Table 4 suggested a positive relationship between: (a) FTK and product involvement $\left(\mathrm{H}_{1 \mathrm{a}}=0.65 ; \mathrm{t}=7.686 ; \mathrm{p}<.001\right) ;(\mathrm{b})$ and trust $\left(\mathrm{H}_{1 \mathrm{~b}}=0.42 ; \mathrm{t}=4.676 ; \mathrm{p}<.001\right)$; that is, FTK has a positive effect on Millennials' product involvement and trust. Thus, supporting hypotheses are $\mathrm{H}_{1 \mathrm{a}}, \mathrm{H}_{1 \mathrm{~b}}$. However, the relationship linking FTK to WTP a premium was not significant $(\mathrm{p}=.758)$, that is, FTK had no significant effect on the Millennials WTP a premium. Therefore, $\mathrm{H}_{1 \mathrm{c}}$ was rejected. As $\mathrm{H}_{2 \mathrm{a}}$ predicts, product involvement has a positive effect on the Millennials' trust $\left(\mathrm{H}_{2 \mathrm{a}}=0.47 ; \mathrm{t}=6.376 ; \mathrm{p}<.001\right)$. Consistent with $\mathrm{H}_{2 \mathrm{~b}}$, the relationship between product involvement and WTP a premium is positive and significant $\left(\mathrm{H}_{2 \mathrm{~b}}=0.34 ; \mathrm{t}=3.414 ; \mathrm{p}<.001\right)$. These results indicate that Hypotheses $\mathrm{H}_{2 \mathrm{a}}$ and $\mathrm{H}_{2 \mathrm{~b}}$ are supported. $\mathrm{H}_{3}$ predicted that Millennials' trust has a positive effect on WTP a premium for Fairtrade products. Hence support for $\mathrm{H}_{3}$ was found $\left(\mathrm{H}_{3}=\right.$ $0.16 ; \mathrm{t}=2.349 ; \mathrm{p}<.05)$.

Table 4: The Model of the Study

\begin{tabular}{|c|c|c|c|c|c|c|}
\hline $\begin{array}{l}\text { Exogenous } \\
\text { constructs }\end{array}$ & $\begin{array}{c}\text { Endogenous } \\
\text { constructs }\end{array}$ & Hypothesis & Estimate & S.E. & t-ratio & $\mathbf{p}$ \\
\hline \multirow{3}{*}{ FTK } & PI & $\begin{array}{c}\mathrm{H}_{\mathrm{la}} \\
\text { (Supported) }\end{array}$ & .60 & .13 & 4.757 & $* * *$ \\
\hline & $\mathrm{T}$ & $\begin{array}{c}\mathrm{H}_{1 \mathrm{~b}} \\
\text { (Supported) }\end{array}$ & .18 & .09 & 2.035 & .042 \\
\hline & WTP & $\begin{array}{c}\mathrm{H}_{\mathrm{lc}} \\
\text { (Not supported) }\end{array}$ & -.03 & .11 & -.308 & .758 \\
\hline \multirow{2}{*}{ PI } & $\mathrm{T}$ & $\begin{array}{c}\mathrm{H}_{2 \mathrm{a}} \\
\text { (Supported) }\end{array}$ & .47 & .07 & 6.376 & $* * *$ \\
\hline & WTP & $\begin{array}{c}\mathrm{H}_{2 \mathrm{~b}} \\
\text { (Supported) }\end{array}$ & .34 & .1 & 3.414 & $* * *$ \\
\hline $\mathbf{T}$ & WTP & $\begin{array}{c}\mathrm{H}_{3 \mathrm{a}} \\
\text { (Supported) }\end{array}$ & .31 & .11 & 2.879 & .004 \\
\hline
\end{tabular}

Note: $* * p<0.01$ 


\section{Discussion}

The Fairtrade (FT) approach has been increasing the awareness of consumers, organizations and the media for over a decade now. The current study proposes that a number of constructs may be relevant to Millennials when considering their willingness to pay (WTP) for Fairtrade products. Focusing on Turkish Millennials, the present study characterizes their FT knowledge, their trust in FT, their product involvement, and analyzes a combination of these factors in terms of WTP.

The study stressed that FT knowledge is the basis of antecedent trust in Fairtrade and product involvement. Thus, the hypotheses "FT knowledge has a significant impact on Millennials' trust in FT" $\left(\mathrm{H}_{1 \mathrm{a}}\right)$ and "FT knowledge has a significant impact on Millennials' product involvement" $\left(\mathrm{H}_{1 \mathrm{~b}}\right)$ were supported. Particularly noteworthy is that the relationship between FT knowledge and product involvement $(\beta=.600)$ is stronger than the relationship between FT knowledge and trust in FT $(\beta=.183)$. This supports the notion that Millennials' fair product knowledge influences the factors (ethical and social responsibility) that come into play in identifying their involvement with the product (De Pelsmacker \& Janssen, 2006) more than their trust in the Fairtrade product itself. The findings indicate that there is not a significant relationship between FT knowledge and WTP. The hypothesis that "FT knowledge has a significant impact on Millennials' WTP a premium" is thus rejected $\left(\mathrm{H}_{1 \mathrm{c}}\right)$. Contrary to the findings of previous studies (Bang et al., 2000; Nakano et al., 2013), the present study claims that people with more knowledge of Fairtrade tend not to pay a higher price for Fairtrade products. The findings of this study do not support the assumption that FT knowledge affects WTP a premium. Previous studies have reported that people with more knowledge of Fairtrade tend to pay the higher price for the product (Nakano et al., 2013; Sing \& Pandey, 2018). The difference in these findings may be due to the fact that previous research looked at renewable energy, green products and packed or Fairtrade products using different approaches.

In addition, the study demonstrates that trust in FT has a significant positive relationship with both product involvement and WTP a premium $\left(\mathrm{H}_{2 \mathrm{a}}, \mathrm{H}_{2 \mathrm{~b}}\right)$. The inference of trust that Millennials have about Fairtrade products affects their WTP a premium for that product. Furthermore, Millennials' trust in Fairtrade products increases product involvement and the belief in them being safer, more ethical, and more sustainable than non-Fairtrade products, and this situation justify the higher price. These findings appear to echo previous research results on product involvement (Alexander \& Nicholls, 2006; Pedregal \& Ozcaglar-Toulouse, 2011; Davenport \& Low, 2013) and WTP a premium (Krystallis \& Chryssohoidis, 2005; Pedragal \& Ozcaglar-Touluse, 2011; Langen \& Adenauer, 2013; Kapusuz \& Kimzan, 2016; Habibov et al., 2017). The following hypotheses are thus accepted $-\mathrm{H}_{2 \mathrm{a}}, \mathrm{H}_{2 \mathrm{~b}}$.

Also, the study reveals that Fairtrade product involvement has a significant relationship with WTP a premium. The hypothesis that "FT product involvement has a significant impact on Millennials' WTP a premium" is therefore accepted $\left(\mathrm{H}_{3}\right)$. In this research, if Turkish Millennials have a belief that the product is more ethical or healthier, they are more willing to pay a premium price. In the same light, the relationship between WTP a premium and product involvement has been noted by previous studies (Campell et al., 2015; O'Connor et al., 2017; Zhang et al., 2018). 


\section{Managerial Implications}

The findings of this study have some implications for marketers with regard to the importance of FT knowledge, FT trust and product involvement in terms of increasing the willingness of individuals to pay for FT products. Furthermore, the results of this study provide insight for marketers with regard to developing their marketing strategies for improving the sales of FT products and to reach targeted Millennial consumers. Firstly, marketing efforts and promotions by marketers focusing on Fairtrade products should stress the social and ethical attributes of these products in order to gain Millennials' trust. For example, Fairtrade products should emphasize that they are ethical and safe and produced without child labor or growth stimulants. Secondly, the Fairtrade organization should focus on creating a high degree of product involvement, because this has a strong effect on willingness to pay a premium for Fairtrade products. For example, companies should launch targeted young consumer communication and information campaigns to enhance consumer involvement and to create positive attitudes towards Fairtrade products. Also, organizations could apply the 'young customer communication' strategy in order to promote Fairtrade products. For example, Turkish schools and universities may offer Fairtrade products to young people in cafes to increase high-product involvement. The present study indicates that trust in Fairtrade products might induce a greater level of WTP a premium for Fairtrade products. Marketers should focus on strategies and activities to increase young peoples' trust in Fairtrade activities. This might be significant in terms of creating in Millennials the WTP a premium for Fairtrade products. The results of this study maintain that a structure for Fairtrade product involvement influences decisions regarding WTP a premium. For example, an increasing interest in Fairtrade products should enhance the young consumers' willingness to engage in the purchase of ethical products at premium prices. Therefore, targeted promotional messages may impact on the spending behavior of young consumers in terms of Fairtrade product offers.

\section{Theoretical Contributions}

The findings of the research make several contributions to the literature on organizational practices. This study adds to the overall understanding of the WTP for Fairtrade products by analyzing the ethical consumer behavior of Millennials. The theoretical model investigates the relationships between Fairtrade knowledge, trust, product involvement and WTP a premium price. The "Fairtrade buying behavior" model of De Pelsmacker was extended in this study. In the model of De Pelsmacker, fair trade buying behavior depends on Fairtrade knowledge, product interest, product likeability, and price acceptability. The main contribution of the research was to analyze the generation's Fairtrade buying behavior that plays a significant role in the purchasing of products and services within many sectors. In this paper, the Fairtrade buying behavior" model of De Pelsmacker was joined with the O'Cass "Product Involvement Model". Besides, a willingness to pay a premium for Fairtrade products depends on more focused constructs such as Fairtrade knowledge, trust and product involvement. 


\section{Limitations and Conclusion}

There are several limitations with regard to the present study that could motivate further research. Although this study focuses on the Millennials, consumers are of a range of different age groups, education and responsibility levels (Roberts, 1995; Hiller \& Benson, 2002). Future research should test the model in differing groups, such as baby boomers and generation $\mathrm{Z}$, or use a specific experimental design such as the theory of planned action to explain consumers' subjective or normative norms, so that the results of this study can be better extended. WTP a premium for a Fairtrade product may be affected by product type and attributes. Hence, future research may analyze consumer perception towards different Fairtrade product types such as chocolate, cotton, etc. Future studies may also choose to look at some additional drivers such as purchasing involvement, consumer preferences and the attributes that explain the ethical behavior of consumers. The paper is concluded by debating the growing influence of young consumer's demands for Fairtrade products. The purpose of this study was to develop these disciplines theoretically, by investigating the Fairtrade consumer behavior of Turkish Millennials from a multilayered view and additionally, to investigate methods through which Fairtrade knowledge, trust and product involvement affects consumers' willingness to pay a premium for Fairtrade goods. The research uses O'Cass and De Pelsmacker's models to examine the prediction of Millennials Fairtrade goods purchasing behavior in the context of Turkey. In this research, O'Cass and De Pelsmacker research has been progressed and broadened to examine Turkish consumers purchasing behavior.

\section{References}

Adesope, A. A. A., Awoyemi, T. T., Falusi, A. O., \& Omonona, B. T., (2010), Willingness to pay for safety label on sugar and vegetable oil among households in South-Western Nigeria, Journal of Agriculture and Social Research, vol. 10, no. 1, pp. 156 - 166.

Ajzen, I., Joyce, N., Sheikh, S., \& Cote, N. G., (2011), Knowledge and the prediction of behavior: The role of information accuracy in the theory of planned behavior, Basic and Applied Social Psychology, vol. 33, no. 2, pp. 101-117.

Alexander, A., \& Nicholls, A., (2006), Rediscovering consumer-producer involvement: A network perspective on Fairtrade marketing, European Journal of Marketing, vol. 40, no. (11/12), pp. 1236-1253.

Atkinson, L., \& Rosenthal, S., (2014), Signaling the green sell: The influence of eco-label source, argument specificity, and product involvement on consumer trust, Journal of Advertising, vol. 43, no. 1, pp. 33-45.

Baker, T. L., Hunt, J. B., \& Scribner, L. L., (2002), The effect of introducing a new brand on consumer perceptions of current brand similarity: The roles of product knowledge and involvement, Journal of Marketing Theory and Practice, vol. 10, no. 4, pp. 4557.

Bang, H. K., Ellinger, A. E., Hadjimarcou, J., \& Traichal, P. A., (2000), Consumer concern, knowledge, belief, and attitude toward renewable energy: An application of the reasoned action theory, Psychology and Marketing, vol. 17, no. 6, pp. 449-468.

Barber, B., (1983), The logic and limits of trust, Rutgers University Press.

Barber, N., Taylor, D. C., \& Deale, C. S., (2010), Wine tourism, environmental concerns, and purchase intention, Journal of Travel and Tourism Marketing, vol. 27, no. 2, pp. 146165. 
Becchetti, L., \& Rosati, F. C., (2007), Global social preferences and the demand for socially responsible products: Empirical evidence from a pilot study on Fairtrade consumers, World Economy, vol. 30, no. 5, pp. 807-836.

Bezençon, V., \& Blili, S., (2009), Fairtrade managerial practices: Strategy, organisation and engagement, Journal of Business Ethics, vol. 90, no. 1, pp. 95-113.

Blackwell, R. D., Miniard, P. W., \& Engel, J. F., (2001), Consumer behavior, South-Western Thomas Learning.

.Bo, Z., Huan, Z., Meizi, L., Qin, Z., \& Jifeng, H., (2017), Trust traversal: A trust link detection scheme in social network, Computer Networks, vol. 120, pp. 105-125.

Campell, J., Dipietro, R. B., \& Remar, D., (2014), Local foods in a university setting: Price consciousness, product involvement, price/quality inference and consumer's willingness-to-pay, International Journal of Hospitality Management, vol. 42, pp. 3949.

Carrigan, M., \& Attalla, A., (2001), The myth of the ethical consumer-do ethics matter in purchase behaviour?, Journal of Consumer Marketing, vol. 18, no. 7, pp. 560-578.

Carson, R. T., (1991), Constructed markets in measuring the demand for environmental quality.

Carter, R. E., (2009), Will consumers pay a premium for ethical information?, Social Responsibility Journal, vol. 5, no. 4, pp. 464-477.

Castaldo, S., Perrini, F., Misani, N., \& Tencati, A., (2009), The missing link between corporate social responsibility and consumer trust: The case of Fairtrade products, Journal of Business Ethics, vol. 84, no. 1, pp. 1-15.

Cerri, J., Testa, F., \& Rizzi, F., (2018), The more I care, the less I will listen to you: How information, environmental concern and ethical production influence consumers' attitudes and the purchasing of sustainable products, Journal of Cleaner Production, vol. 175, pp. 343-353.

Chater, M., (1992), Greener marketing: A responsible approach to business, Greenlesf Sheffield.

Creyer, E. H., \& Ross Jr, W. T., (1997), Tradeoffs between price and quality: How a value index affects, Journal of Consumer Affairs, vol. 31, no. 2, pp. 280-302.

D'Amico, M., Di Vita, G., \& Monaco, L., (2016), Exploring environmental consciousness and consumer preferences for organic wines without sulfites, Journal of Cleaner Production, vol. 120, pp. 64-71.

Davenport, E., \& Low, W., (2013), From trust to compliance: Accountability in the fairtrade movement, Social Enterprise Journal, vol. 9, no. 1, pp. 88-101.

Davies, I. A., \& Crane, A., (2003), Ethical decision making in fairtrade companies, Journal of Business Ethics, vol. 45, no. 1-2, pp. 79-92.

De Pelsmacker, P., \& Janssens, W., (2007), A model for fairtrade buying behaviour: The role of perceived quantity and quality of information and of product-specific attitudes, Journal of Business Ethics, vol. 75, no. 4, pp. 361-380.

De Pelsmacker, P., Driesen, L., \& Rayp, G., (2005), Do consumers care about ethics? willingness to pay for fair - trade coffee, Journal of Consumer Affairs, vol. 39, no. 2, pp. 363-385.

De Pelsmacker, P., Janssens, W., Sterckx, E., \& Mielants, C., (2006), Fair - trade beliefs, attitudes and buying behaviour of Belgian consumers, International Journal of Nonprofit and Voluntary Sector Marketing, vol. 11, no. 2, pp. 125-138.

Dodd, T. H., Laverie, D. A., Wilcox, J. F., \& Duhan, D. F., (2005), Differential effects of experience, subjective knowledge, and objective knowledge on sources of information used in consumer wine purchasing, Journal of Hospitality and Tourism Research, vol. 29, no. 1, pp. 3-19.

Euromonitor, (2018), “Turkey", Retrieved from http://www.portal.euromonitor.com/portal/r esultslist/index

Fairtrade International, (2014), “Our mission”, Retrieved from https://info.fairtrade.net/ 
Fairtrade Labelling Organizations, (2018), “About fairtrade”, Retrieved from https://www.fairtrade.net/about-fairtrade/fairtrade-and-you/researching-fairtrade.html

Felix, R., Gaynor, G., Pevzner, M., \& Williams, J. L., (2017), Societal trust and the economic behavior of nonprofit organizations, Advances in Accounting, vol. 39, pp. 21-31.

Forbes, (2018), "How to tap into the millennial $\$ 200$ billion buying power with social media", Retrieved from https://www.forbes.com/sites/julesschroeder/2017/10/31/how-to-tapinto-the-millennial-200-billion-buying-power-with-social-media/

Fornell, C., \& Larcker, D. F., (1988), Structural equation models with unobservable variables and measurement error: Algebra and statistics, Journal of Marketing Research, vol. 18 , no.3, pp. 382-388.

Fraj, E., \& Martinez, E., (2006), Environmental values and lifestyles as determining factors of ecological consumer behaviour: An empirical analysis, Journal of Consumer Marketing, vol. 23, no. 3, pp. 133-144.

Gerrard, C., Janssen, M., Smith, L., Hamm, U., \& Padel, S., (2013), UK consumer reactions to organic certification logos, British Food Journal, vol. 115, no. 5, pp. 727-742.

Govindasamy, R., DeCongelio, M., Italia, J., Barbour, B., \& Anderson, K., (2001), Empirically evaluating consumer characteristics and satisfaction with organic products, New Jersey Agricultural Experiment Station, P-02139-1-01.

Greenwald, A. G., \& Leavitt, C., (1984), Audience involvement in advertising: Four levels, Journal of Consumer Research, vol. 11, no. 1, pp. 581-592.

Habibov, N., Cheung, A., \& Auchynnikava, A., (2017), Does social trust increase willingness to pay taxes to improve public healthcare? Cross-sectional cross-country instrumental variable analysis, Social Science and Medicine, vol. 189, pp. 25-34.

Harrison, R., Newholm, T., \& Shaw, D., (2005), The ethical consumer, Sage Publications.

Hiller, K., \& Benson, E., (2014), Fairtrade consumption from the perspective of US baby boomers, Social Responsibility Journal, vol. 10, no. 2, pp. 364-382.

Hobbs, J. E., \& Goddard, E., (2015), Consumers and trust, Food Policy, vol. 52, pp. 71-74.

Hong, I. B., (2015), Understanding the consumer's online merchant selection process: The roles of product involvement, perceived risk, and trust expectation, International Journal of Information Management, vol. 35, no. 3, pp. 322-336.

Hughner, R. S., McDonagh, P., Prothero, A., Shultz, C. J., \& Stanton, J., (2007), Who are organic food consumers? A compilation and review of why people purchase organic food, Journal of Consumer Behaviour: An International Research Review, vol. 6, no. (2 - 3), pp. 94-110.

Janssen, M., \& Hamm, U., (2012), Product labelling in the market for organic food: Consumer preferences and willingness-to-pay for different organic certification logos, Food Quality and Preference, vol. 25, no. 1, pp. 9-22.

Janssen, M., \& Hamm, U., (2014), Governmental and private certification labels for organic food: Consumer attitudes and preferences in Germany, Food Policy, vol. 49, pp. 437448.

Jones, A. R., \& Williams, G., (2012), Perceptions of fairtrade labelling and certification: Three case studies, Journal of Fashion Marketing and Management: An International Journal, vol. 16, no. 2, pp. 246-265.

Jones, P., Comfort, D., \& Hillier, D., (2003), Retailing fairtrade food products in the UK, British Food Journal, vol. 105, no. 11, pp. 800-810.

Kapusuz, S., \& Kimzan, H. S., (2016), The role of fairtrade trust on the relationship of fairtrade knowledge, fairtrade adhesion, and willingness to pay fairtrade premium: The case of Turkey, Turkish Journal of Business Ethics, vol. 9, no. 1, pp. 70-89.

Kim, G. S., Lee, G. Y., \& Park, K., (2010), A cross-national investigation on how ethical consumers build loyalty toward fairtrade brands, Journal of Business Ethics, vol. 96, no. 4 , pp. 589-611.

Krier, J. M., (2001), Fairtrade in Europe 2001: Facts and figures on the fairtrade sector in 18 European countries, Maastricht: EFTA Research Report.

Ladhari, R., \& Tchetgna, N. M., (2015), The influence of personal values on fairtrade consumption, Journal of Cleaner Production, vol. 87, pp. 469-477. 
Lamb, P. W., \& Liesch, P. W., (2002), The internationalization process of the smaller firm: Re-framing the relationships between market commitment, knowledge and involvement, Management International Review, vol. 42, no. 1, pp. 7-26.

Langen, N., \& Adenaeuer, L., (2013), Where does the fairtrade price premium go? Confronting consumers' request with reality, Social Enterprise Journal, vol. 9, no. 3, pp. 293-314.

Laroche, M., Bergeron, J., \& Goutaland, C., (2003), How intangibility affects perceived risk: The moderating role of knowledge and involvement, Journal of Services Marketing, vol. 17, no. 2, pp. 122-140.

Liang, Y. P., (2012), The relationship between consumer product involvement, product knowledge and impulsive buying behavior, Procedia-Social and Behavioral Sciences, vol. 57, pp. 325-330.

Lin, L. Y., \& Chen, C. S., (2006), The influence of the country-of-origin image, product knowledge and product involvement on consumer purchase decisions: An empirical study of insurance and catering services in Taiwan, Journal of Consumer Marketing, vol. 23 , no. 5, pp. 248-265.

Lissitsa, S., \& Kol, O., (2016), Generation X vs. Generation Y-A decade of online shopping, Journal of Retailing and Consumer Services, vol. 31, pp. 304-312.

Liu, P. J., Dallas, S. K., Harding, M., \& Fitzsimons, G. J., (2018), The sales impact of featuring healthy foods, indulgent foods, or both: Findings from a large-scale retail field study, Journal of the Association for Consumer Research, vol. 3, no. 3, pp. 346363.

López-Mosquera, N., García, T., \& Barrena, R., (2014), An extension of the theory of planned behavior to predict willingness to pay for the conservation of an urban park, Journal of Environmental Management, vol. 135, pp. 91-99.

Low, W., \& Davenport, E., (2005), Has the medium (roast) become the message? The ethics of marketing fairtrade in the mainstream, International Marketing Review, vol. 22, no. 5, pp. 494-511.

Jin Ma, Y., Littrell, M. A., \& Niehm, L., (2012) Young female consumers' intentions toward fairtrade consumption, International Journal of Retail \& Distribution Management, vol. 40, no. 1, pp.41-63.

Mai, L. W., (2014), Consumers' willingness to pay for ethical attributes, Marketing Intelligence and Planning, vol. 32, no. 6, pp. 706-721.

Maignan, I., Ferrell, O. C., (2004), Corporate social responsibility and marketing: An integrative framework, Journal of the Academy of Marketing Science, vol. 32, no. 1, pp. 3-19.

McKnight, D. H., Cummings, L. L., \& Chervany, N. L., (1998), Initial trust formation in new organizational relationships, Academy of Management Review, vol. 23, no. 3, pp. 473490.

Moses, E., (2000), The $\$ 100$ billion allowance: Accessing the global teen market, John Wiley and Sons.

Muhcina, S., \& Popovici, V., (2015), Few aspects concerning the marketing particularities in healthcare services, Series Economic Sciences, vol. 15, no. 2, pp. 300-305.

Murakami, J., (2018), The government land sales programme and developers' willingness to pay for accessibility in Singapore, 1990-2015, Land Use Policy, vol. 75, pp. 292-302.

Nakano, D., Muniz Jr, J., \& Dias Batista Jr, E., (2013), Engaging environments: Tacit knowledge sharing on the shop floor, Journal of Knowledge Management, vol. 17, no. 2, pp. 290-306.

Nijssen, E., Uijl, R., \& Bucklin, P., (1995), The effect of involvement on brand extensions, In Proceedings of the 24th Annual EMAC Conference, ESSEC, Paris, France.

Nunnally, J., (1978), Psychometric theory, McGraw-Hill.

O'Cass, A., (2000), An assessment of consumers product, purchase decision, advertising and consumption involvement in fashion clothing, Journal of Economic Psychology, vol. 21, no. 5, pp. 545-576. 
O'Connor, E. L., Sims, L., \& White, K. M., (2017), Ethical food choices: Examining people's fairtrade purchasing decisions, Food Quality and Preference, vol. 60, pp. 105-112.

Park, C. W., \& Moon, B. J., (2003), The relationship between product involvement and product knowledge: Moderating roles of product type and product knowledge type, Psychology and Marketing, vol. 20, no. 11, pp. 977-997.

Pedregal, V. D., \& Ozcaglar - Toulouse, N., (2011), Why does not everybody purchase fairtrade products? The question of the fairness of fairtrade products' consumption for consumers, International Journal of Consumer Studies, vol. 35, no. 6, pp. 655-660.

Petty, R. E., Cacioppo, J. T., \& Goldman, R., (1981), Personal involvement as a determinant of argument-based persuasion, Journal of Personality and Social Psychology, vol. 41, no. 5, pp. 847-855.

Pinto, D. C., Nique, W. M., Añaña, E. D. S., \& Herter, M. M., (2011), Green consumer values: how do personal values influence environmentally responsible water consumption?, International Journal of Consumer Studies, vol. 35, no. 2, pp. 122131.

Poelman, A., Mojet, J., Lyon D., \& Sefa-Dedeh, S., (2008), The influence of information about organic production and fairtrade on preferences for and perception of pineapple, Food Quality and Preference, vol. 19, no. 1, pp. 114-121.

Rashid, M. S., \& Byun, S. E., (2018), Are consumers willing to go the extra mile for fairtrade products made in a developing country? A comparison with made in USA products at different prices, Journal of Retailing and Consumer Services, vol. 41, pp. 201-210.

Raynolds, L. T., (2012), Fairtrade: Social regulation in global food markets, Journal of Rural Studies, vol. 28, no. 3, pp. 276-287.

Raynolds, L. T., Murray, D., \& Taylor, P., (2004), Fairtrade coffee: Building producer capacity via global networks, Journal of International Development, vol. 16, no. 8, pp. 1109-1121.

Reinstein, D., \& Song, J., (2012), Efficient consumer altruism and fairtrade products, Journal of Economics and Management Strategy, vol. 21, no. 1, pp. 213-241.

Ribbink, D., Van Riel, A. C., Liljander, V., \& Streukens, S., (2004), Comfort your online customer: Quality, trust and loyalty on the internet, Managing Service Quality: An International Journal, vol. 14, no. 6, pp. 446-456.

Roberts, J. A., (1995), Profiling levels of socially responsible consumer behavior: A cluster analytic approach and its implications for marketing, Journal of Marketing Theory and Practice, vol. 3, no. 4, pp. 97-117.

Rotter, J. B., (1967), A new scale for the measurement of interpersonal trust, Journal of Personality, vol. 35, no. 4, pp. 651-665.

Rotter, J. B., (1971), Generalized expectancies for interpersonal trust, American Psychologist, vol. 26, no. 5, pp. 443-452.

Rousseau, S., (2015), The role of organic and fairtrade labels when choosing chocolate, Food Quality and Preference, vol. 44, pp. 92-100.

Sama, C., Crespo-Cebada, E., Díaz-Caro, C., Escribano, M., \& Mesías, F. J., (2018), Consumer preferences for foodstuffs produced in a socio-environmentally responsible manner: A threat to fairtrade producers?, Ecological Economics, vol. 150, pp. 290296.

Shaw, D., \& Clarke, I., (1999), Belief formation in ethical consumer groups: An exploratory study, Marketing Intelligence and Planning, vol. 17, no. 2, pp. 109-120.

Shaw, D., \& Shiu, E., (2002), An assessment of ethical obligation and self - identity in ethical consumer decision - making: A structural equation modelling approach, International Journal of Consumer Studies, vol. 26, no. 4, pp. 286-293.

Singh, G., \& Pandey, N., (2018), The determinants of green packaging that influence buyers' willingness to pay a price premium, Australasian Marketing Journal, vol. 26, no. 3, pp. $221-230$. 
Sriwaranun, Y., Gan, C., Lee, M., \& Cohen, D. A., (2015), Consumers' willingness to pay for organic products in Thailand, International Journal of Social Economics, vol. 42, no. 5, pp. 480-510.

Stoica, I., Vegheş, C., \& Orzan, M., (2015), Statistical exploratory marketing research on romanian consumer's behavior regarding smartphones, Procedia Economics and Finance, vol. 32, pp. 923-931.

Strong, C., (1996), Features contributing to the growth of ethical consumerism-a preliminary investigation, Marketing Intelligence and Planning, vol. 14, no. 5, pp. 5-13.

Tallontire, A., Rentsendorj, E., \& Blowfield, M., (2001), Ethical consumers and ethical trade: A review of current literature, NRI Policy Series 12, pp. 1-35.

Traylor, M. B., (1981), Product involvement and brand commitment, Journal of Advertising Research, vol. 21, no. 6, pp. 51-56.

Trudel, R., \& Cotte, J., (2009), Does it pay to be good?, MIT Sloan Management Review, vol. 50 , no. 2, p. 61.

Tükel, İ., Tüketimin, Y. A., (2014), Y Kuşağ1, Ankara, pp. 1-22.

Van den Broeck, E., Poels, K., \& Walrave, M., (2018), An experimental study on the effect of ad placement, product involvement and motives on Facebook ad avoidance, Telematics and Informatics, vol. 35, no. 2, pp. 470-479.

Wang, C. C., Chen, C. A., \& Jiang, J. C., (2009), The impact of knowledge and trust on econsumers' online shopping activities: An empirical stud, Journal of Computers, vol. 4, no. 1, pp. 11-18.

Wier, M., Jensen, K. O. D., Andersen, L. M., \& Millock, K., (2008), The character of demand in mature organic food markets: Great Britain and Denmark compared, Food Policy, vol. 33, no. 5, pp. 406-421.

Wiser, R. H., (2007), Using contingent valuation to explore willingness to pay for renewable energy: A comparison of collective and voluntary payment vehicles, Ecological Economics, vol. 62, no. 3-4, pp. 419-432.

Wongpitch, S., Minakan, N., Powpaka, S., \& Laohavichien, T., (2016), Effect of corporate social responsibility motives on purchase intention model: An extension, Kasetsart Journal of Social Sciences, vol. 37, no. 1, pp. 30-37.

Young, M. E., \& McCoy, A. W., (2016), Millennials and chocolate product ethics: Saying one thing and doing another, Food Quality and Preference, vol. 49, pp. 42-53.

Zaichkowsky, J. L., (1985), Measuring the involvement construct, Journal of Consumer Research, vol. 12, no. 3, pp. 341-352.

Zak, P. J., \& Knack, S., (2001), Trust and growth, The Economic Journal, vol. 111, no. 470, pp. 295-321.

Zhang, B., Fu, Z., Huang, J., Wang, J., Xu, S., \& Zhang, L., (2018), Consumers' perceptions, purchase intention, and willingness to pay a premium price for safe vegetables: A case study of Beijing, China, Journal of Cleaner Production, vol. 197, pp. 14981507. 